1 Lassen J, Kapperud G. Epidemiological aspects of enteritis due to campylobacter in Norway. $\mathcal{F}$ Clin Microbiol 1984;19:153-6.

2 Pitkanen T, Ponka S, Pettersson T, Kosunen T. Campylobacter enteritis in 188 hospitalised patients. Arch Intern Med 1983;43:215-9.

3 Shmilovitz M, Kretzer B, Rotman N. Campylobacter jejunii as an etiologicaalgent of diarrheal diseases in Israel. Isr F Med Sci 1982;18:935-40.

4 Robins-Browne RM, Mahehdra K, Mackenjee MB, Marilyn N, Coovadia M. Treatment of campylobacter-associated enteritis with erythromycin. Am $\mathcal{f}$ Dis Child

Mackowiak PA. Microbial synergism in human infections. N Engl $\mathcal{F}$ Med 1978;

-6, 84-6.

(Accepted 31 May 1985)

Department of Pediatrics, Tel Aviv Medical Center, Rokah Hospital, Tel Aviv, Israel

I MELAMED, MD, paediatrician

Y BUJANOVER, MD, consultant gastroenterologist

Z SPIRER, MD, professor and head of department

Microbiology Laboratory, Sackler Faculty of Medicine, Tel Aviv University, Israel

D SCHWARTZ, MSC, microbiologist

N CONFORTY, MSC, head of laboratory

Correspondence to: Professor Spirer.

\section{Campylobacter colitis with intestinal aphthous ulceration mimicking obstruction}

We report what we believe to be the first case of aphthous ulceration of the intestine in a child with colitis due to campylobacter. This child had the characteristic mucosal lesions of herpetic gingivostomatitis,

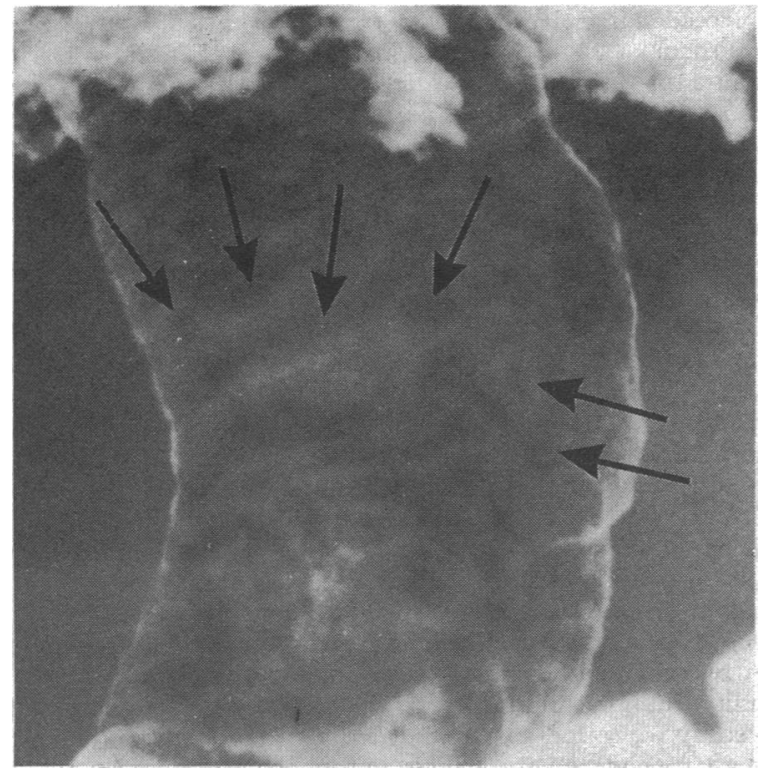

$X$ ray film showing numerous aphthous ulcers (arrowed) present in colon in campylobacter colitis.

which also have not been recorded before with this particular bowe infection. The stools did not contain blood or mucus, and the initial tentative diagnosis was of bowel obstruction.

\section{Case report}

A 7 year old boy presented with a five day history of intermittent periumbilical pain and was referred to us because of suspected obstruction. Two other children attending his school and using the same dining room had acute enteritis. Within this cluster one child was eventually found to have campylobacter in his stool. Our patient had severe vomiting and became more than $10 \%$ dehydrated. A swinging fever with a peak at $40^{\circ} \mathrm{C}$ was observed. The stools were loose but at no time contained blood or mucus; they were characterised by being malodorous. In addition he had glossitis and gingivitis. He did not have ocular or genital signs of inflammation to suggest Behçet's disease.

When he was admitted to hospital his diarrhoea, which had been a prominent feature, resolved and a stool could not readily be obtained for culture. To avoid a delay in establishing the diagnosis, however, a rectal swab was cultured and produced a heavy growth of campylobacter. Other pathogens known to be associated with colitis, such as amoebas, salmonella, shigella, and yersinia, were not recovered.

The results of investigations were: haemoglobin concentration $131 \mathrm{~g} / 1$; white cell count $8.2 \times 10^{9} / 1$; erythrocyte sedimentation rate $5 \mathrm{~mm}$ in the first hour; negative results of a Widal test; amylase activity $195 \mathrm{U} / 1$ (normal 70$300 \mathrm{U} / 1)$; sodium concentration $145 \mathrm{mmol}(\mathrm{mEq}) / 1$; results of amoebic complement fixation test 1/16, of Paul-Bunnell (Monospot) test negative, of cytomegalovirus complement fixation test $<1$ in 2 , and of toxoplasma fluorescence antibody test negative; total protein concentration $61 \mathrm{~g} / \mathrm{l}$ (normal $60-80 \mathrm{~g} / 1$ ); albumin concentration $49 \mathrm{~g} / 1$ (normal 32-50 g/1); gammaglobulin concentration $20 \mathrm{~g} / \mathrm{l}$ (normal $20-40 \mathrm{~g} / \mathrm{l}$ ); and Coxsackie B virus titres not significant. A nose swab yielded Haemophilus influenzae and Staphylococcus aureus, and a throat swab yielded normal flora. No virus was seen on electron microscopy of stool, and a midstream specimen of urine yielded no cells or growth. A radiograph of the abdomen showed distended bowel with several fluid levels in the colon. Because the pain, vomiting, and fever persisted a double contrast barium enema was performed (figure), and this showed extensive fine aphthous ulceration of the large bowel. We were not given permission to carry out sigmoidoscopy and rectal biopsy or small bowel radiological and histological studies to exclude Crohn's disease (discrete (or aphthoid) ulcers are a characteristic and common finding in Crohn's disease of the colon).

He responded rapidly and completely to erythromycin $20 \mathrm{mg} / \mathrm{kg} /$ day. As the colitis resolved clinically so did the oral problem.

\section{Comment}

Aphthous ulceration of the colon in childhood has not been reported before, although campylobacter colitis has been described. ${ }^{2}$ Moreover, glossitis and gingivitis have not previously been noted in campylobacter colitis. Ellis et al, however, reported a mouth ulcer in an adult with the disease. ${ }^{3}$ Our patient showed that campylobacter colitis can present with some features suggesting bowel obstruction rather than colitis, and in such cases there is a risk of unnecessary laparotomy, particularly if a patient is referred directly to a surgeon. Although taking a rectal swab is often impugned as a diagnostic method, ${ }^{4}$ it is worth while in avoiding delay in establishing the diagnosis in the rare cases in which a stool cannot be obtained.

1 Max RJ, Kelvin FM. Nonspecificity of discrete colonic ulceration on double contrast barium enema study. Amer $\mathcal{f}$ Roentgenol 1980;134:1265-7.

Guandalini S, Cucchiara S, de Ritis $G$ et al Campylobacter colitis in infants. f Pediatr 1983;102:72-4.

Ellis ME, Pope J, Mokashi A, Dunbar E. Campylobacter colitis associated with erythema nodosum. Br Med $\mathcal{f} 1982 ; 285: 937$.

4 Silverman A, Roy CC. Pediatric clinical gastroenterology. London: C V Mosby, 1983.

(Accepted 13 May 1985)

Hammersmith Hospital, London W12 0HS

D BENTLEY, MSC, MRCP, honorary consultant paediatrician

J LYNN, MS, FRCS, consultant endocrine surgeon

King's College Hospital, London SE5 9RS

J W LAWS, FRCP, FRCR, director of radiology

Correspondence to: Dr Bentley.

\section{Topical rubefacient ointment: studies on haemostasis}

Rubefacient ointments are widely used for the treatment of musculoskeletal pain, often with concurrent oral analgesia. These compounds generally consist of salicylate esters, heparinoids, and nicotinic acid esters, a combination designed to enhance the anti-inflammatory and analgesic effects of the individual substances.

Systemic absorption of any of the active ingredients may disturb the haemostatic mechanism, ${ }^{2-4}$ and the concurrent use of aspirin would aggravate any effect. Animal studies show systemic effects and detect- 
able plasma and urinary salicylate after topical rubefacient application. We performed a study to examine the effect of topical rubefacient on the haemostatic mechanism in man.

\section{Methods}

Ten healthy adult volunteers applied $10 \mathrm{~g}$ of Bayolin (benzyl nicotinate, glycol salicylate, and a heparinoid) to each calf on two separate occasions. On one occasion $600 \mathrm{mg}$ of aspirin was taken 12 hours earlier, and on a third occasion the effect of $600 \mathrm{mg}$ aspirin alone was examined. The three tests were performed randomly at three week intervals. No drugs were permitted during the study.

A series of studies were carried out before and 45 minutes after Bayolin application: blood count, prothrombin time, partial thromboplastin time, thrombin time, plasma fibrinogen, fibrinolytic screen (plasminogen activator, plasminogen and $a_{2}$-plasmin inhibitor concentrations), platelet studies (aggregation to collagen and serum thromboxane $\mathbf{B}_{2}$ concentrations), chromogenic substrate assays of heparin and factor $\mathrm{Xa}_{\mathrm{a}}$ and plasma salicylate concentrations. A subjective score $(0-4)$ of the intensity of the cutaneous response was recorded and compared with an objective assessment of this response.

\section{Results}

All volunteers experienced heat, erythema, and paraesthesia in the area of application with a maximal response 20 to 40 minutes after application. Individual variation in the intensity of response was noted. The subjective response correlated well with an objective assessment of severity. Four individuals had a pronounced response (score 3-4), the mean response being $2 \cdot 4$ (SD 1.1). Ingestion of aspirin before the test greatly reduced or abolished the cutaneous response to ointment (mean $0.3(0.5)$ ).

The blood count, coagulation screen, and fibrinolytic activity were unaltered by topical rubefacient irrespective of aspirin (table). Plasma heparin activity and salicylate were undetectable after rubefacient alone. Topical rubefacient produced no change in serum thromboxane $B_{2}$ concentra tions, but inhibition of platelet aggregation to a collagen dose of $5 \mu \mathrm{g} / \mathrm{ml}$ occurred $(p<0.05)$. Aspirin administered before the tests abolished platelet aggregation and reduced the serum thromboxane $B_{2}$ concentration.

Inhibition of platelet aggregation after rubefacient was most apparent in the four volunteers with a pronounced cutaneous response. Their mean aggregation to collagen $(5 \mu \mathrm{g} / \mathrm{ml})$ fell from $84(9) \%$ to $54(15) \%$ and the dose giving $50 \%$ aggregation (median effective dose) increased from $0.56(0.37)$ $\mu \mathrm{g} / \mathrm{ml}$ to $1 \cdot 17 \mu \mathrm{g} / \mathrm{ml}$

\section{Discussion}

Inhibition of platelet aggregation to collagen $5 \mu \mathrm{g} / \mathrm{ml}$ is the only detectable haemostatic abnormality after application of a single dose of Bayolin. The greater inhibition observed in volunteers with an intense cutaneous response may indicate that after intense erythema greater absorption of salicylate occurred, though this was still below detectable concentrations. This observation is consistent with animal studies showing enhanced epicutaneous absorption of salicylate when nicotinic acid benzyl ester was added.

Inhibition of the cutaneous response to rubefacients by oral analgesia has been previously observed. ${ }^{5}$ If these compounds have any analgesic effect it is probably mediated through the cutaneous symptoms evoked. While this study suggests that topical rubefacient does not produce appreciable haemostatic defects in man, it appears that concurrent aspirin may noticeably impair any beneficial local effect.

We thank Dr J Conkie and Miss F McCall for technical help and Bayer Pharmaceuticals for their support.

1 Marmo E, Matera A. Experimental evaluation of an anti-inflammatory agent Arzneimittelforsch 1973;23:846-51.

Thiessen JJ. Aspirin: plasma-concentrations and effects. Thromb Res 1983 (suppl IV): $105-11$
3 Thomas DP, Lane DA, Michalski R, Johnson EA, Kakkar VV. A heparin analogue with specific action on antithrombin III. Lancet 1977; i:120-2 Weiner M, Redisch W, Steele JM. Occurrence of fibrinolytic activity following administration of nicotinic acid. Proc Soc Exp Biol Med 1958;98:755-7.

5 Dixon AS, Henderson D. Prescribing for osteoarthritis. Prescribers' Journal $1973 ; 13: 41-9$.

(Accepted 16 May 1985)

Department of Haematology, Royal Infirmary, Glasgow G4 OSF

C R J SINGER, BSC, MRCP, registrar in haematology

H HAMBLEY, BSC, MRCPATH, senior registrar in haematology

I D WALKER, MD, MRCPATH, consultant haematologist

J F DAVIDSON, FRCP, FRCPATH, consultant haematologist

Correspondence to: Dr C R J Singer, Department of Haematology, Faculty of Clinical Sciences, University College London, London WC1E 6HX.

\section{Cutaneous amoebiasis: case report}

Amoebiasis, whether presenting as colitis, hepatic abscess, or empyema, may be misdiagnosed in Britain, particularly in patients who have never been abroad. ${ }^{1}$ The much rarer cutaneous amoebiasis is also likely to be underdiagnosed; this is particularly so when it affects the abdomen after laparotomy, because the spreading gangrene of the skin closely mimics the postoperative synergistic gangrene of Meleney, with which it has been confused. ${ }^{2}$ We report a further example of this mistake.

\section{Case report}

A 21 year old man who had recently returned from the Far East was admitted on 4 September 1965 with fever $\left(37.8^{\circ} \mathrm{C}\right)$ and severe pain in the left hypochondrium and in the back. The white cell count was $13 \times 10^{9} / 1$ with a neutrophil leucocytosis. A fortnight later a tender epigastric swelling was found between the left costal margin and the lateral border of the left rectus abdominis. The history of foreign travel and the leucocytosis suggested an amoebic liver abscess but there had been no diarrhoea or dysentery, repeated examination of stools showed no amoebas, and result of the complement fixation test was negative. Surgical exploration of the swelling produced 250 $\mathrm{ml}$ of white pus. The cause of the abscess was obscure. It did not communicate with the liver or spleen and on culture there was no bacterial growth.

Drainage of the abscess relieved the pain but a fortnight later it returned. The white cell count had risen to $19 \times 10^{9} / 1$ and the abscess was therefore reopened and drained. Subsequently the wound edges became black, exquisitely tender, and intensely painful. The gangrenous process spread outwards across the abdomen, and the triple zonation (a central slough, a raised purplish black margin, and an outer, bright red zone of hyperaemia) of Meleney's bacterial gangrene became apparent. The classical treatment of radical excision of the edges of the ulcerated area failed to halt the spread and the patient's condition deteriorated, owing largely to the intolerable pain

At this stage the ulceration occupied a large part of the upper abdomen (figure) but Entamoeba histolytica (strongly positive result on periodic acid Schiff staining) had been identified in sections prepared from the excised wound margins. The diagnosis was changed to cutaneous amoebiasis. Antiamoebic treatment (dehydroemetine $80 \mathrm{mg}$ daily subcutaneously) was begun and within 48 hours a dramatic improvement occurred. The pain resolved completely and the patient felt and looked much better. The gangrene of the ulcer edges began to fade and healing began, becoming complete some three months later (figure). The patient resumed his occupation and when last seen in August 1984 was well.

\section{Comment}

Amoebiasis may affect patients who have never been out of Britain.' Cutaneous amoebiasis has often escaped early diagnosis because it

\begin{tabular}{|c|c|c|c|c|c|c|c|c|c|c|}
\hline & \multirow{2}{*}{\multicolumn{3}{|c|}{ Coagulation studies }} & \multirow{2}{*}{\multicolumn{4}{|c|}{ Fibrinolysis studies }} & \multicolumn{3}{|c|}{ Platelet studies } \\
\hline & & & & & & & & & Aggregation & Aggregation \\
\hline & $\begin{array}{c}\text { Thrombin } \\
\text { time }(\mathbf{s})\end{array}$ & $\begin{array}{c}\text { One stage } \\
\text { prothrombin } \\
\text { time (s) }\end{array}$ & $\begin{array}{c}\text { Activated } \\
\text { partial } \\
\text { thromboplastin } \\
\text { time (s) }\end{array}$ & $\begin{array}{c}\text { Plasminogen } \\
\text { activator } \\
\text { (fibrin plate } \\
\text { mm) }\end{array}$ & $\begin{array}{c}\text { Plasminogen } \\
\left(0_{0}^{0}\right)\end{array}$ & $\begin{array}{c}\mathrm{a}_{2}-\text { Plasmin } \\
\text { inhibitor } \\
\left(\mathrm{o}_{0}\right)\end{array}$ & $\begin{array}{l}\text { Fibrinogen } \\
(\mathbf{g} / \mathbf{l})\end{array}$ & $\begin{array}{l}\text { Serum } \\
\text { thromboxane } \\
\mathbf{B}_{2}(\mathrm{ng} / \mathrm{ml})\end{array}$ & $\begin{array}{c}\text { (median } \\
\text { effective dose }) \\
(\mu \mathrm{g} \text { collagen } / \\
\mathrm{ml})\end{array}$ & $\begin{array}{c}\text { to } 5 \mu \mathrm{g} \\
\text { collagen } / \mathrm{ml} \\
\text { ( } \% \\
\text { maximum) }\end{array}$ \\
\hline $\begin{array}{l}\text { Before application } \\
\text { After application }\end{array}$ & $\begin{array}{l}7(1) \\
7(1)\end{array}$ & $\begin{array}{l}14(1) \\
14(1)\end{array}$ & $\begin{array}{l}41(4) \\
41(5)\end{array}$ & $\begin{array}{l}11 \cdot 8(3 \cdot 2) \\
13 \cdot 4(2 \cdot 2)\end{array}$ & $\begin{array}{l}89 \cdot 7(5 \cdot 7) \\
92 \cdot 8(9 \cdot 5)\end{array}$ & $\begin{array}{l}93 \cdot 2(7 \cdot 2) \\
94.3(5 \cdot 9)\end{array}$ & $\begin{array}{l}2.5(0.6) \\
2.5(0.5)\end{array}$ & $\begin{array}{l}226(173) \\
224(115)\end{array}$ & $\begin{array}{l}0.53(0.26) \\
0.77(0.59)\end{array}$ & $\begin{array}{l}84 \cdot 5(6 \cdot 8) \\
71 \cdot 1(17 \cdot 5)\end{array}$ \\
\hline
\end{tabular}

